\title{
The need to improve transport conditions in the big cities of Romania
}

\author{
V. Rădulescu, I. Străinescu, L. Moroianu, E. Tudor, C. Goia, \\ F. Bozaș, V. Lupu, B. Rădulescu \& M. Tănase \\ ICPE SAERP S.A. Bucharest, Romania
}

\begin{abstract}
The development of the great cities in Romania, especially of the capital, Bucharest, and the exaggerated increase of the number of cars, mostly used cars from Western Europe, have contributed to the pollution of these cities and resulted in a horrific urban traffic, particularly during the morning and evening rush hours. This paper will examine the decision factors and the planning concerns to provide better conditions for urban transport in Bucharest and in the other great cities in Romania, especially with regard to urban electrical vehicles. Although the fleet of urban transport vehicles is based on electrical vehicles, because of the traffic jam during rush hours, satisfaction of passengers is low, with the exception of the light-rail and metro passengers. This makes more people use their personal car when they go to work or shopping (even single occupancy), resulting in terrible traffic. This was the reason light-rail transportation was developed in Bucharest and in major cities of Romania. In order to encourage the usage of the urban transportation means, especially electrical ones, we have proposed some measures to improve the comfort provided by the urban public transport vehicles. The company ICPE SAERP Bucharest, specialized in the production of electrical traction drives and auxiliary converters, is developing and continuously improving the equipment and services concerning auxiliary services equipment, converters for air conditioning systems, access to traffic information, transport quality, unified fares for surface transportation (trams, trolleybuses and buses) and underground transportation, easy access vehicles, safety, security and cleanliness.

Keywords: modern transit, trams, trolleybuses, light metro, subway lines, capacity, travel time, light rail.
\end{abstract}




\section{Introduction}

To ensure better transportation in Bucharest and surroundings, RATB uses a network of $60 \mathrm{~km}$ with 3 Light Rail - LR lines, over $300 \mathrm{~km}$ tramcar lines with a park of almost 500 tramcars, 18 trolleybus lines with a park of 300 trolleybuses and a bus park of 1300 [2]. The public transportation network in Bucharest depends also on the 4 underground lines, which improves the capacity and time of the transportation.

During rush hour, the tram and trolley lines are most of the time obstructed by cars so the average transport speed is $8 . .10 \mathrm{~km} / \mathrm{h}$ for trams and $6 . . .9 \mathrm{~km} / \mathrm{h}$ for trolley buses. The rest of day the averages are $10 \ldots 14 \mathrm{~km} / \mathrm{h}$ for trams and $9 . .14 \mathrm{~km} / \mathrm{h}$ for trolley buses.

From the analysis done by various authorities in Europe, in Japan and in the USA we concluded that the pollution in the big cities may be reduced if a wellorganised urban transportation system with modern means of transportation can be ensured. By modern means of transportation we refer especially to those that use underground and surface light metro - LM, completed by connection lines with tramcars, trolley buses, electrical buses and hybrid fuel cell buses (that have a parallel connection for supplying the traction system through modern electrical storage batteries) [2].

\section{Global measures regarding urban transport vehicles}

Concerning Bucharest - the capital (10\% of the population and $18 \%$ of the GBP), the next step is increasing the capacity of the road transportation network, according to the PMB Master Plan [3], elaborated by the Bucharest City Hall for the 2008-2027 period. An important measure from this plan is the construction of a railway circle around Bucharest that would connect seven railway stations through a double line. This would ensure at least 4 all-electric EMU (electric multiple unit) per hour each way on this double line and it wishes to reduce transport by car in Bucharest [3]. Unfortunately, this project has been put on hold during the recession.

In 2012, the drillings for the 5th metro line in Bucharest started, designed to connect the western neighbourhood of "Drumul Taberei" with downtown Bucharest by 2015 and later with the eastern part of the city.

During this recession period, concerning the transportation in major cities, which is based on trams, it is very important to completely modernise the tracks and the trams [4].

\section{Trams: the modernisation of the rolling stock}

In Bucharest, where there is a fleet of more than 300 trams - most of them being very old, it is important to have a budgetary modernization of the trams in such a manner that the trams shall be able to operate on the light metro lines, before the introduction of other modern trams. 


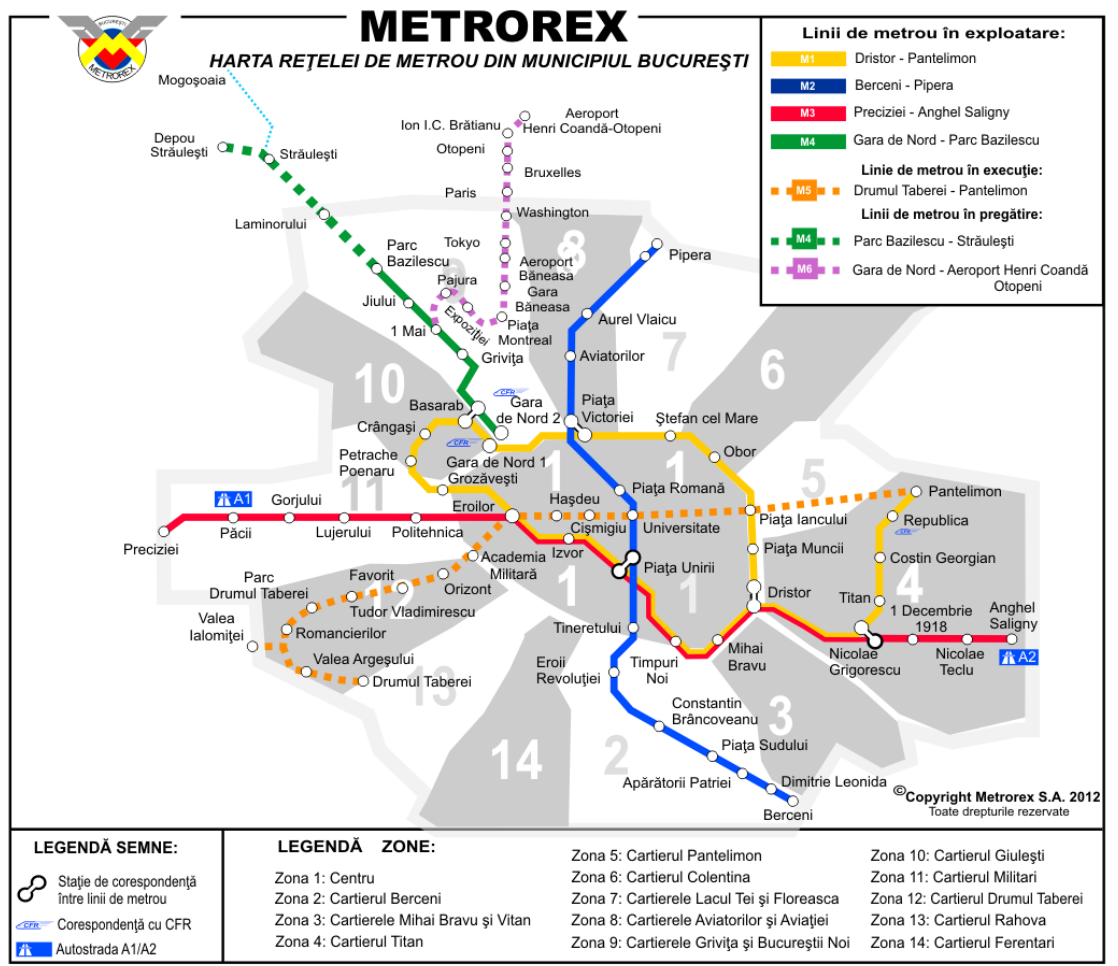

Figure 1: $\quad$ The map of the Bucharest metro in 2013.

The rolling stock in Romania consists of hundreds of trams and several special wagons used for line maintenance. Most of the trams were produced in Romania and some of them are used trams imported from Europe. The comfort level is low, the safety and reliability is variable and is subject of technical improvements performed at the exploitation companies.

\subsection{New trams produced in Romania}

The Romanian industry has good references in the urban transport vehicles, especially those based on electrical traction. Trams were produced in the past in Romania at the RATB-URAC Bucharest, Electroputere Craiova and Electrometal Timisoara.

\subsubsection{Bucur low-floor BLF by RATB-UR Bucharest}

In the last years, the public transport company of Bucharest (RATB-UR) together with ICPE SAERP have been developing a new tram called Bucur Low Floor BLF, which is a six axles articulated three-section vehicle with AC traction equipment produced by ICPE SAERP, air conditioning, 70\% low floor and comes at a very good price. There are 10 units in operation since 2012 and the production shall continue with 10 trams each year from now on. 


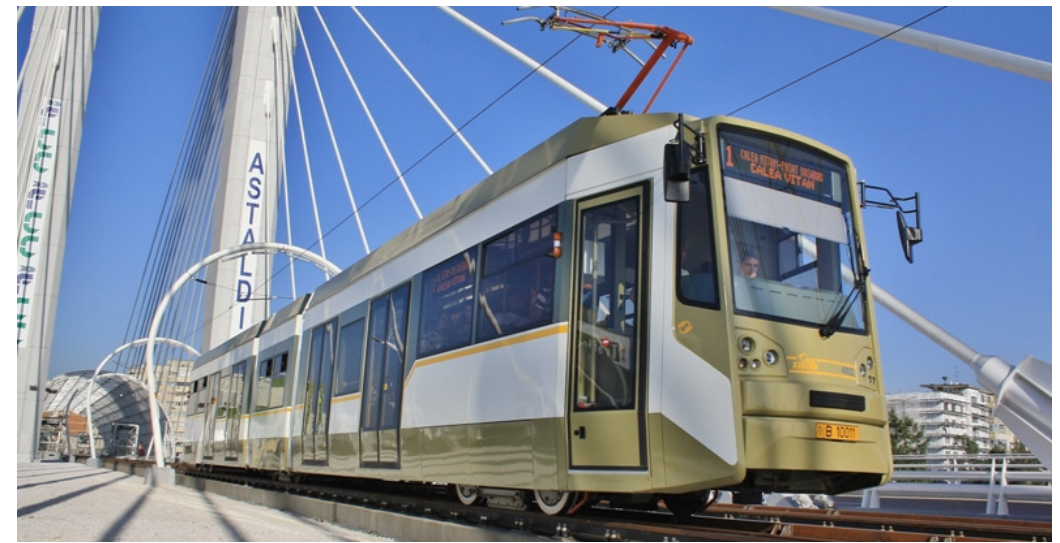

Figure 2: $\quad$ Romanian tram BLF on the Basarab Bridge in Bucharest.

The main characteristics of the BLF trams are:

Model

Axel arrangement

Gauge

Maximum speed

Line Voltage

Car body length

Vehicle minimum/ max weight

Total passengers
: Six axles articulated three-section vehicle

: B'1'1'B

: $1435 \mathrm{~mm}$

: $60 \mathrm{~km} / \mathrm{h}$

: 750 Vdc (+20-30\%)

: $27180 \mathrm{~mm}$

$: 34$ / $54 \mathrm{t}$

: 249.

\subsubsection{Imperio by Astra Vagoane Arad}

The wagon producer "ASTRA Vagoane Calatori" located in Arad, in cooperation with Siemens and using components from several Romanian

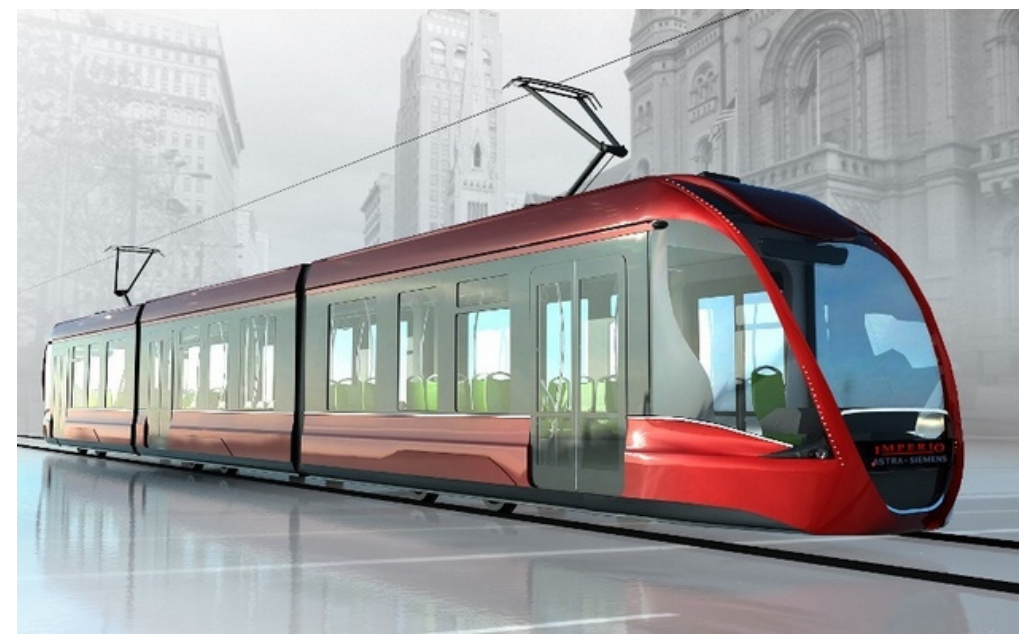

Figure 3: $\quad$ The rendering of the Astra-Imperio tram made for Romania. 
companies (including ICPE SAERP) is developing a new tram called "Imperio". This new tram has $100 \%$ low floor, AC current traction equipment, air conditioning and an on-board camera.

\subsection{Modernisation and refurbishment of old trams}

By using the old chassis and bogies, in the last years the Romanian tram suppliers perform maintenance and repair works. Also, by replacing the traction equipment and by adding some comfort improvements they offer a cheaper solution of replacing trams.

The particularities of the electric system of the tram:

- Optimised design with IGBT technology;

- $\quad$ Simplified cabling by using serial control bus;

- PWM Pulse-field oriented control (FOC) control unit built-in the traction inverters;

- Jerk free starting and braking;

- Combined regenerative and rheostat braking;

- $\quad$ On-line diagnose and black-box memory.

\subsubsection{The tram type V3A-2010CA in Bucharest}

This tram is using the old chassis of V3A tram produced in RATB-URAC, which uses 4 bogies and 3 sections, has a new AC traction systems and modern control equipment, doors and brakes. The modernisation took place in the refurbishment line of RATB-URAC and consists of:

- $\quad$ Replacement of the used DC motors with new AC motors;

- Removing of the cables, contactors and resistors;

- Installing of the traction equipment;

- $\quad$ Renewing the cabin with modern controls and displays;

- Installing an air conditioning unit for the driver;

- Installing a system of information displays;

- $\quad$ Modern ticketing system with magnetic cards;

- $\quad$ Auxiliary battery charger with Mosfet transistors;

- Door management.

The specifications are:

Model

: Eight axles articulated three-section vehicle

Axel arrangement

: B'2'2'B

Gauge

: $1435 \mathrm{~mm}$

Maximum speed

: $60 \mathrm{~km} / \mathrm{h}$

Line Voltage

Car body length

: 750 Vdc (+20-30\%)

Vehicle minimum/ max weight

$: 27180 \mathrm{~mm}$

Total passengers

$: 35$ / $55 \mathrm{t}$

: 249 . 


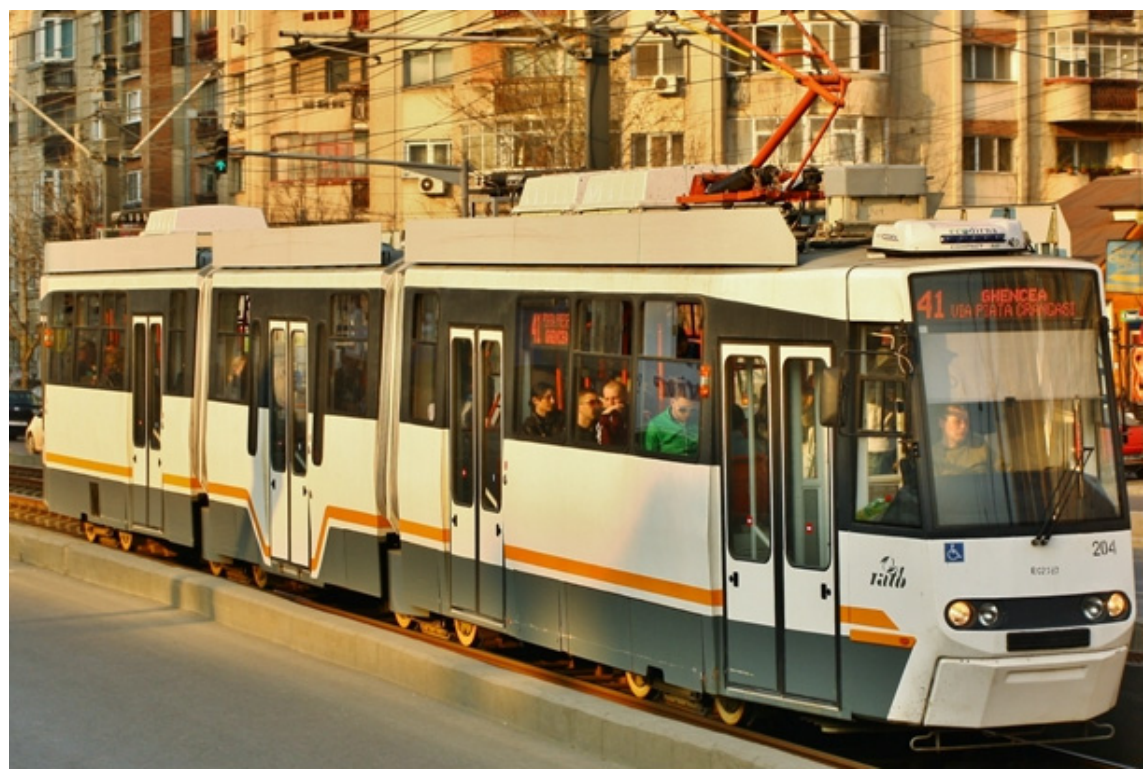

Figure 4: $\quad$ The V3A-2010-CA with traction inverters in Bucharest.

There are 49 trams of this type in normal operation that were produced between 2005 and 2010.

\subsubsection{The example of a modernisation of the GT4-CA in Iasi}

REMAR Pascani and ICPE SAERP performed the modernisation of the old GT4 tram. The new tram is prepared for the city of Iasi. Practically, the tram is rebuilt from an old tram GT4, initially in service in Halle, Germany. The equipment installed on the tram is using the top technologies applied on similar trams on the market. Operations performed mainly consist of:

a. The replacement of the DC traction system;

b. The removal of the DC rheostat;

c. The installation of the new traction system (on the roof);

d. The installation of two air conditioning units and air ducts;

e. The installation of an auxiliary converter for the HVAC units;

f. The installation of a battery charger with Mosfet transistors;

g. The installation of a new pneumatic brake systems, including park brake;

h. Installation of a new electro-magnetic brake system;

i. Complete new interior of the tram;

j. Installation of a new heating system;

k. Developing a complete new cabin, front desk and displays;

l. The installation of a new ticketing system;

$\mathrm{m}$. The installation of new displays, both indoor and outdoor;

n. A new exterior look, including front and rear part facelift. 


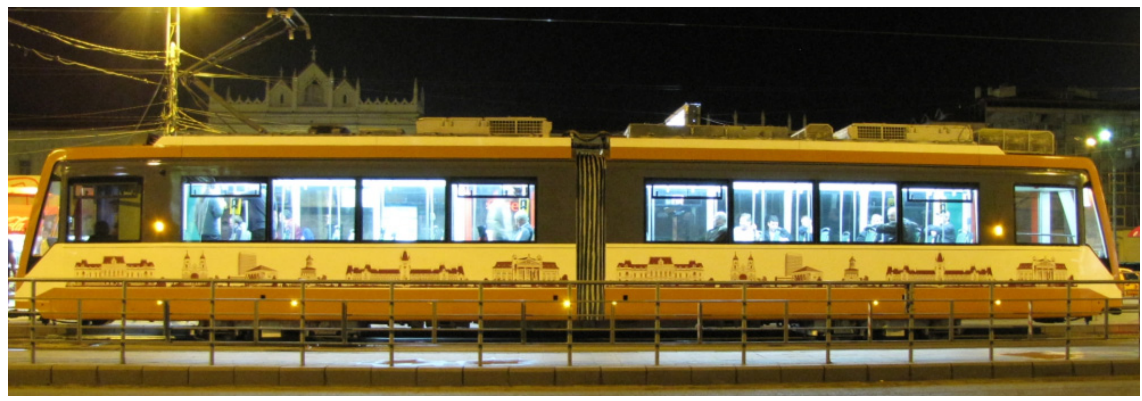

Figure 5: $\quad$ Tests during the night with the GT4-CA tram in Iasi.

However, by maintaining the old chassis structure and the bogies from the old GT4, the maximum speed has not increased.

By using better and safer brakes, bigger traction motors with higher brake torque; the brake behaviour is heightened, this being the main reason of the modernisation. Also, the improved comfort is an extra benefit for passengers in Iasi.

Due to the contribution of the local producers, this tram costs half of the price of a similar new one, being a very attractive solution for cities aiming to have a modern fleet of trams.

\subsection{Proposed trams suitable for Romanian cities}

In Romania the interest of renewing the trams has a strong response from big producers like Siemens, Alstom or Bombardier, but also from the regional tram builders like Pesa and Polaris (from Poland), Koncjear (from Serbia) and Skoda (from Czech Republic).

All of these proposals must be modified in order to be used on the Romanian network, either by increasing the gauge from $1000 \mathrm{~mm}$ to $1435 \mathrm{~mm}$, or by using equipment with higher nominal voltage and cables able to operate on the $750 \mathrm{Vdc}$ systems (instead of the $600 \mathrm{Vdc}$ used across Europe). These special requirements do affect the price of the foreign trams on the Romanian market, so the local builders have an additional advantage.

\section{The rehabilitation of the tram runway in major cities}

Public transport in the large cities of Romania is relying on the trams, especially in downtown and in the industrial areas. The industrial activity has been changed in the last 20 years, and the transport needs were modified accordingly.

However, the rails developed during the communist industrial expansion in the 1980s represent the most important part of the tram network. This network is a connection between the high-density residential areas and the industrial ones. That is the reason for the old network modernisation. 


\subsection{The tram railway was replaced in Bucharest, prepared for operation as light-metro}

The tram network of Bucharest consists of:

- 25 tram lines and 593 stations;

- 507 trams, from which 323 are large capacity trams;

- 34 million trips with trams per year (45\%);

- 23.6 million kilometres per year;

- 207.2 kilometres average trip per tram.

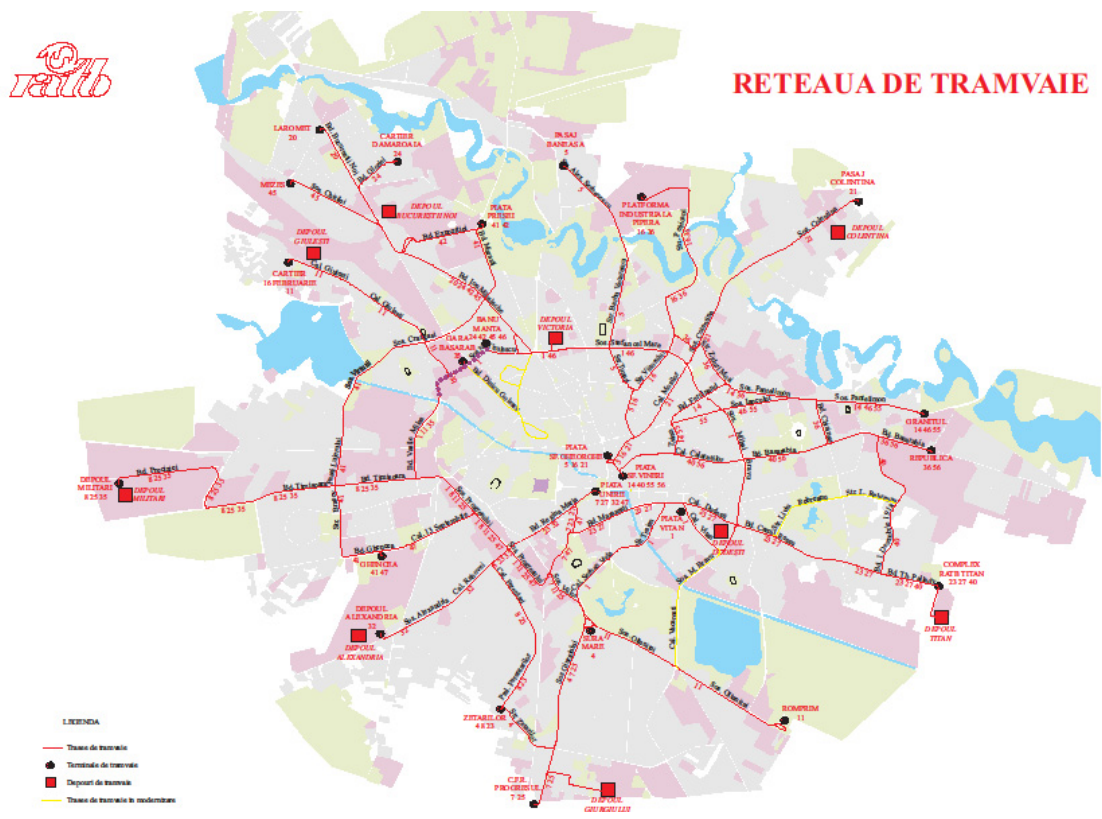

Figure 6: Tram network of Bucharest.

The infrastructure of trams in Bucharest was subject to a massive modernisation in the last 12 years, which consists of:

Track replacement for $160 \mathrm{~km}$ double track;

Switch replacements (56 switches);

Aerial network replaced, including holding pillars;

288 Stations replacement and modernisations;

Line separations for $45 \mathrm{~km}$.

The most important achievement of the tram network modernisation is: - route 41 (18.6 km of railway separated from traffic with 30 stations). 


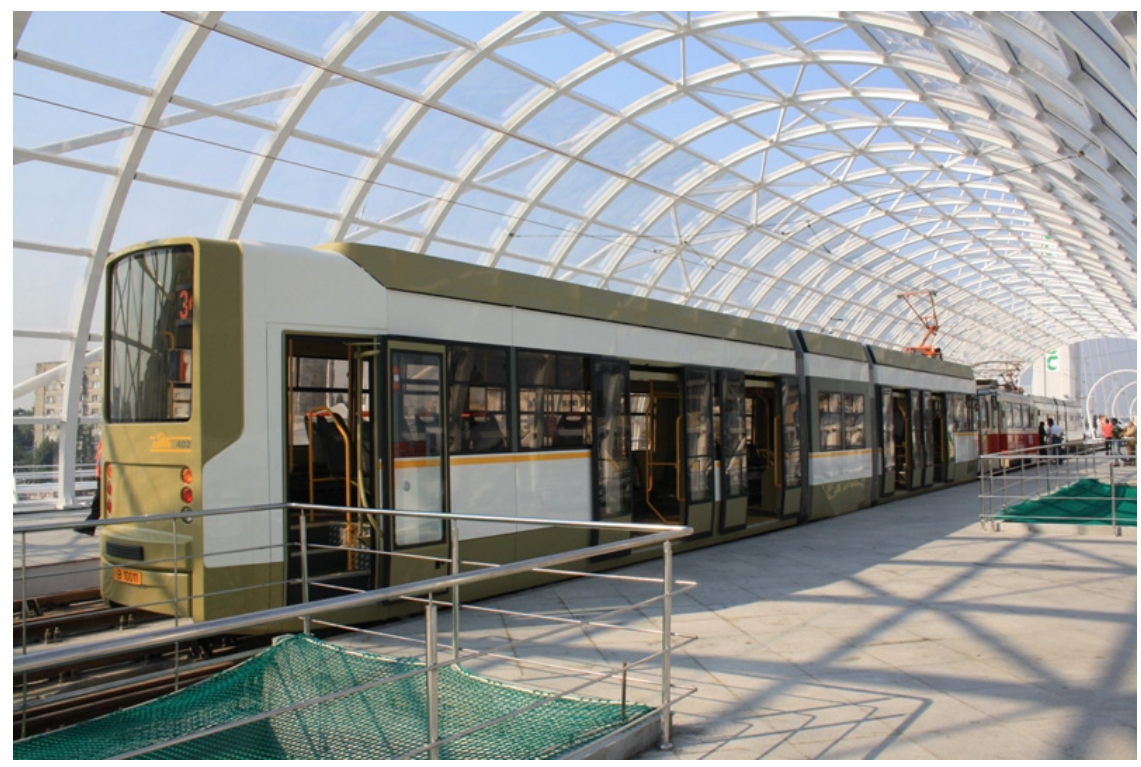

Figure 7: $\quad$ Modern tram station on the Basarab Bridge.

\subsection{Investments proposed and implemented in other cities}

Arad is a city with old tradition in tram operated lines. They managed to replace all the lines in downtown with major investments.

The trams in Cluj-Napoca (centre of the traditional region of Transylvania) are using double line of $13.2 \mathrm{~km}$, all renewed between 2009 and 2012 .

Planned road rehabilitation in Timisoara solved $75 \%$ of the tram network, between 2006 and 2009.

In Iasi there are $76 \mathrm{~km}$ of double track. There are 8 lines operated by 150 trams. The modernisation that started in 2010 will replace $40 \%$ of the lines, especially the major transit ones.

\subsection{The trams in Romania: trends and perspectives}

In the last 20 years the electric urban transport has seen a decline. In many cities the tram and trolley bus lines were removed and replaced by bus lines. Once we became part of the European Union the urban transportation policy has changed and the authorities were forced to reintroduce electric vehicles. Romanian manufacturers also developed new, more efficient and comfortable means of electrical transportation, by themselves or in cooperation with other Romanian or foreign companies.

For all new urban transport vehicles in Romania, some requirements must be fulfilled:

1. A universal payment system has been implemented in Bucharest in order to simplify the payment of transport fares for surface and underground urban 
transportation. This implies the use of a special pre-pay card that can be recharged and can be used for both surface (ensured by RATB) and underground (ensured by METROREX) transportation.

2. Urban transportation vehicles will be equipped with systems to assist disabled persons and people carrying baby strollers. For this purpose in the last two years all the new trolleybuses, light rail frames and trams have low floor. In Bucharest there is one low floor trolleybus for every two normal ones, over the EU norm of 1:3 vehicles. Regarding trams, the ratio is unfortunately still way below the EU norm - there is 1 low floor tram for every 30 normal ones.

3. All the urban transportation vehicles will be equipped with audio and video information systems that will transmit the name of the next station, the commuting information, the date and the time, the GPS position and the map.

4. Video surveillance is implemented in order to increase the safety of the passengers and to be used in legal matters.

5. Energy measurements must be available and will be used to optimize the traffic limitations, the traffic frequency and to improve the driver's behaviour.

\subsection{Tram as an investment of the municipality}

The municipality of a big city in Romania is responsible of the public transport system. Each city can decide, according to the Master Plan, when and where a high capacity transport vehicle is needed. Although the initial investment amount is important, the long-term benefits can cover those expenses.

Meanwhile, for the cities which already have trams, it is good to have a longterm policy of development, for both industrial and residential areas. Also, the tram must be renewed in order to be attractive for the passengers in terms of comfort and speed.

\subsection{New lines: tram or light metro?}

Concerning the development of new lines, the light metro is a fairly good recommendation. But the vehicles must be compatible with the existing transport network to ensure the interoperability and optimisation of the maintenance. A system with independent track, such as the light metro lines, will have more efficiency than a mixed-route track.

\section{Conclusion}

From the analysis done by various authorities in Europe, in Japan and in the USA, we concluded that the pollution in the big cities may be reduced if a wellorganized urban transportation can be assured, with modern means of transportation, especially those that use:

- The rail track, equipped with an electrical supply line of $25 \mathrm{kV}-50 \mathrm{~Hz}$ or

a $3 \mathrm{kVdc}$ line, to supply the EMU [2]. The existing train stations must also be modernised and in addition four more modern stations must be built. 
- Underground and surface subway networks (on special routes, including light-metro - LM);

- Lines that use tramcars, trolley buses, hybrid fuel cell and electrical buses that have modern electrical storage batteries.

Because of the economical recession, the project of Bucharest circle rail modernisation was stopped and the development of the new underground line number 5 is slowed.

In order to save the electric transport in Romania, as described in this paper, there are designed and produced two new type of trams (which are able to perform light-metro operation) and are refurbished and modernised two types of trams for Bucharest and Iasi.

Some cities of Romania, like Bucharest, Iasi, Cluj, Arad, Timisoara are interested in the acquisition of new trams, with large capacities.

The mayors of some big cities (Brasov, Constanta) are not interested in reducing the pollution we consider that additional taxis shall be imposed for unused electric transportation systems, which is efficient and non polluting.

\section{References}

[1] Green Paper. Towards a new culture for urban mobility. Commission of the European Communities. Brussels, 25.9. 2007.

[2] Străinescu I, Rădulescu V. The Need for Change of the Transport Mode in the Great Cities of Romania Urban Transport XVII - 2011, WIT Press.

[3] Master Plan for Urban Transport in Bucharest. 15.04.2008, General Counsel of Bucharest.

[4] Light Rail and Metro Systems in Europe. Current market, Perspectives and research implication. ERRAC the European Rail Research Advisory Council, 2004.

[5] Rădulescu V, Străinescu I, Moroianu L, Goia C, Tudor E, Bozaş F, Lupu V, Rădulescu B, Tănase M. The need of improvement of transport conditions in the large Romanian cities. Urban Transport XVII -2012, WIT Press. 